\title{
Secondary School Business Educators' Perceptions of the Knowledge, Skills, and Abilities Needed by Information Systems Majors Relative to Other Business Majors
}

\author{
Kevin Berry \\ Bradley University, \\ Peoria, IL, USA
}

kberry42@bradley.edu

\author{
David O'Bryan and Maeve Cummings \\ Pittsburg State University, \\ Pittsburg, KS, USA
}

\author{
obryan@pittstate.edu \\ cummings@pittstate.edu
}

\section{Executive Summary}

The demand for information technology (IT) or information systems (IS) personnel remains strong, despite the cyclical downturn in the technology industry. The field continues to offer good salaries, challenge, and high levels of job satisfaction. The IS profession needs to attract the best and brightest students to the field to satisfy the needs of business. Secondary school educators are a key factor in that effort since research suggests that they often have a significant influence on the career choices of tertiary level students.

This paper reports the results from a survey of 248 secondary school business educators in Illinois regarding their perceptions of the knowledge, skills, and abilities (KSAs) needed by the following business majors: information systems, accounting, finance, management, and marketing. The survey results suggest that secondary school business educators generally have an incomplete and inaccurate opinion of the skills necessary to succeed in the IS profession. IS was not rated highest on any KSA and on nine out of fourteen KSAs, IS was rated lowest - in some cases by quite a large margin.

The results indicate that the IS profession faces a challenge recruiting students away from other professions. Even those students who choose a major in business may not choose IS because of inaccurate perceptions of the profession by secondary school business teachers.

Keywords: secondary school students; secondary school teachers; perceptions of business majors

\section{Introduction}

Material published as part of this journal, either on-line or in print, is copyrighted by the publisher of the Journal of Information Technology Education. Permission to make digital or paper copy of part or all of these works for personal or classroom use is granted without fee provided that the copies are not made or distributed for profit or commercial advantage AND that copies 1) bear this notice in full and 2) give the full citation on the first page. It is permissible to abstract these works so long as credit is given. To copy in all other cases or to republish or to post on a server or to redistribute to lists requires specific permission and payment of a fee. Contact Editor@JITE.org to request redistribution permission.
As the economy rebounds, it will be clear that the need for greater numbers of highly qualified IT professionals has not disappeared (Brown, 2003). Although the growth rate of jobs in information technology (IT) slowed, there were approximately 3.5 million people directly employed in IT positions in September 2003 (Chabrow, 2003). Skilled IT profes- 
sionals continued to be one of the most important success factors for organizations that want to stay competitive. The fact that so many people are involved in the IT function shows that demand crosses industry boundaries and is important to management in all industries. With an estimated ninety-two percent of IT workers working for non-IT companies (ITAA, 2002), this demand crosses industry boundaries and is not simply an IT issue alone.

Secondary school students considering their careers should note that salaries for IT positions have not declined during the economic downturn, with the median pay remaining slightly above $\$ 100,000$ in total compensation (McGee, Chabrow, \& Hayes, 2003). In addition to pay, IT jobs tend to be professionally satisfying. In fact, 80 percent of IT staff and almost 90 percent of managers reported that they found their jobs to be intellectually challenging, and many studies have found that challenge is a vital component of job satisfaction (McGee, et al., 2003).

As optimism about hiring in IT increases, concern over the gap between demand and supply is also apparent (ITAA, 2002). It is clear that the IT profession has a pressing need to attract the best and brightest students into the field. Unfortunately, public perceptions concerning the information technology (IT) profession are inconsistent and unflattering, resulting in the image of a lone, nerdy male scientist with a pocket protector (ITAA, 1998). Ideally, recruitment of students into the IT profession should address these perception problems. And, since many high quality students select a college major while they are in secondary school, efforts should begin before students have chosen a college and career field.

Secondary school educators often have a large influence on students' choice of major. Unfortunately, evidence exists that these key professionals have an inaccurate perception of IT as a career (ITAA, 2002). In addition, there is evidence that those adults with little IT training may actually fear it as a career choice for themselves or others (ITAA, 1998). This uninformed perception of IT by secondary school educators may negatively influence the college major advice they give their students. To counteract this, the Image of the Information Technology Professions Task Force encourages school districts to target school career counselors and K-12 teachers and staff in an effort to evaluate and improve the IT image (McGee, 2001).

This paper explores how a subset of secondary school teachers, namely tertiary level business teachers, perceives information systems (IS) as compared to other business majors on 14 attributes. Survey results from 248 secondary school business teachers suggests the IS profession is perceived rather negatively as compared to other majors these teachers might be recommending to their students.

\section{Purpose}

Literature suggests that a significant number of secondary school students make career choices during their secondary school years (Graves, Nelson, \& Deines, 1993; Nelson \& Deines, 1995) and that it is often too late to change a person's career choice by the time he or she finishes secondary school (Abtan, 1993). A Gallup poll indicated that secondary school teachers are second only to parents as the most important influence on secondary school students' career decisions (Dobson \& Price, 1991). In addition, secondary school students' views are shaped in large part by the advice and counsel of their secondary school teachers and counselors (Dobson \& Price, 1991; Graves et al., 1993; Nelson \& Deines, 1995; Paolillo \& Estes, 1982).

These results suggest that the perception of secondary school educators is paramount in the recruitment of the best and brightest for the IS profession. If these teachers have an inaccurate, incomplete, or uninformed picture of the knowledge, skills, and abilities necessary for success in IS, then their students are likely to select a major based upon misinformation. This could lead to highly qualified prospects choosing a major other than IS. Alternatively, students without the 
requisite skills to succeed in IS might select IS as a major. Either situation is detrimental to the IS profession.

As a preliminary step in exploring this issue, this study focuses on a subset of secondary school teachers, namely secondary school business teachers. Intuitively, the secondary school teachers most likely to advise students to pursue a business-related degree are those teaching businessrelated courses. Advising students to pursue a degree in business can be viewed as the first step in attracting secondary school students into the IS profession. The second step in attracting students into IS is to provide students with accurate information about the IS profession so that they will make an informed decision when selecting a business major. If the students are not presented with accurate information, many students who decide to pursue a degree in business may select a major other than IS, or may select IS based upon inaccurate information conveyed to them by their secondary school business teachers.

The a priori hypothesis of this study is that secondary school business teachers may have inaccurate or incomplete perceptions of the business and communication skills needed to succeed in IS. The purpose of this paper is to explore the perceptions of secondary school business teachers toward information systems relative to alternative business majors, namely accounting, finance, management, and marketing.

\section{Method}

A survey was mailed to 1,050 secondary school business educators in Illinois in 2001. A total of 248 surveys was returned for a response rate of 23.6 percent. Seventy percent of the respondents were female, 65.7 percent held a masters degree or higher, their average age was 45.4 years, and the average number of years they had been teaching was 18.8 .

The research instrument asked respondents to rate, on a scale of 0 (lowest level of ranking) to 100 (highest level), the five business majors listed according to their personal opinion as to the knowledge, skills, and abilities (KSAs) required to succeed in that major. Fourteen KSAs were used to compare the information systems major to accounting, finance, management, and marketing majors. Four versions of the survey were used with the ordering of the KSAs (rows) and the majors (columns) different on each version to mitigate order effects. (An analysis of the four versions revealed no significant differences among the versions.) Thirteen of the 14 KSAs were chosen from among those listed as most important for career success in the Institute of Management Accountant's study, The Practice Analysis of Management Accounting (IMA, 1996). The $14^{\text {th }}$ KSA, the ability to work on a team, was one of the skills singled out as necessary for success in a leading-edge finance organization in the 1999 Practical Analysis (Siegel \& Sorensen, 1999). The Institute of Management Accountants' (IMA) set of KSAs is applicable to any business major and was therefore used in this study. Either interpersonal and communication skills or general business skills and knowledge were the specific KSAs that were chosen. Literature suggests that these are skills required for a productive career in information systems (ITAA, 2002; Medlin, Dave, \& Vannoy, 2001; Weber, McIntyre, \& Schmidt, 2001; Young, 1996). The research instrument is reproduced in the Appendix with the mean responses reported in each cell. Repeated measures ANOVA was then used to determine whether there were significant differences in the ratings between information systems and the alternative business majors listed. (For access to the raw data, contact David O’Bryan at obryan@pittstate.edu)

\section{Results}

Results for the repeated measures ANOVA indicated that respondents' perceptions of information systems were significantly different $(\mathrm{p}<.05)$ from at least two of the four alternative business majors on all 14 KSAs. A brief discussion of these results is organized according to whether infor- 
mation systems differed from two, three, or all four of the alternative majors. Each table presents the mean score for each major and its significance level which indicates whether the score on that major was significantly different from information systems.

Table 1 lists the results for the KSAs that were significantly different from two of the four other business majors. IS was significantly different from two other business majors on four of the KSAs: analytical/problem-solving skills, mathematical skills, listening skills, and work ethic. For analytical/problem solving skills, IS was perceived to be lower than accounting, management, and finance, but higher than marketing. IS was perceived to be significantly different in analyti$\mathrm{cal} /$ problem solving skills needed for success from those needed to succeed by an accounting and marketing major. It did not differ significantly from management and finance. IS was rated significantly lower than both accounting and finance on mathematical skills. IS was marginally $(\mathrm{p}<.06)$ higher than marketing on this KSA. Although management had a higher mean, it was perceived to be comparable on the needs for mathematical skills to be successful with information systems.

Table 1: Information Systems Significantly Different from Two Other Business Majors

\begin{tabular}{|c|c|c|c|c|c|}
\hline \multicolumn{7}{|c|}{ Analytical / Problem-Solving Skills (n= 240) } \\
\hline Major & Accounting & Management & Finance & IS & Marketing \\
\hline Mean & $92.86^{*}$ & 91.84 & $90.28^{* *}$ & 90.23 & $82.46^{* * *}$ \\
\hline \multicolumn{7}{|c|}{ Mathematical Skills (n=240) } \\
\hline Major & Finance & Accounting & Management & IS & Marketing \\
\hline Mean & $97.85^{* * *}$ & $96.55^{* * *}$ & 80.56 & 78.93 & 76.42 \\
\hline \multicolumn{7}{|c|}{ Listening Skills (n=244) } \\
\hline Major & Management & Marketing & Finance & Accounting & IS \\
\hline Mean & $98.23^{* * *}$ & $95.91^{* * *}$ & 85.05 & 84.96 & 83.09 \\
\hline \multicolumn{7}{|c|}{ Work Ethic (n=246) } \\
\hline Major & Management & Accounting & Marketing & Finance & IS \\
\hline Mean & $98.37 * *$ & $97.74 *$ & 97.19 & 97.17 & 96.77 \\
\hline$*$ p-value $<.05 ; * *$ p-value $<.01 ; * * *$ p-value $<.001$ & \\
\hline
\end{tabular}

IS also had the lowest score for both listening skills and work ethic. The score for listening skills was not significantly different from accounting or finance. However, IS was significantly lower than both management and marketing. With all receiving a rating above 96, work ethic was perceived to be highly important for success in all five majors, however, IS received the lowest absolute score. Management and accounting were perceived to be significantly higher on the need for a strong work ethic, while finance and marketing were perceived to be about the same as IS on this attribute.

Table 2 lists the results for the KSAs for which IS was significantly different from three of the four other business majors. Understanding the information needs of internal customers was the only KSA that IS was significantly different from three other majors. The results indicate that IS 
was significantly higher than both finance and accounting on this attribute. However, IS was significantly lower than management and lower but not significantly different from marketing.

\begin{tabular}{|c|c|c|c|c|c|}
\hline \multicolumn{6}{|c|}{ Table 2: Information Systems Significantly Different from Three Other Business Majors } \\
\hline \multicolumn{6}{|c|}{ Understanding the Information Needs of Internal Customers (n=236) } \\
\hline Major & Management & Marketing & IS & Finance & Accounting \\
\hline Mean & $92.28 * * *$ & 82.27 & 80.14 & $75.32 * * *$ & $73.42 * * *$ \\
\hline$*$ p-value $<.05 ; * *$ p-value $<.01 ; * * *$ p-value $<.001$ \\
\hline
\end{tabular}

Table 3 lists the results for the KSAs for which IS was significantly different from the four other business majors. IS was rated significantly lower than all four alternative business majors on the remaining nine KSAs: understanding the business environment, understanding the competitive environment, understanding financial statements, interpersonal skills, leadership skills, negotiation skills, speaking/presentation skills, ability to work on a team, and writing skills.

\begin{tabular}{|c|c|c|c|c|c|}
\hline \multicolumn{6}{|c|}{ Understanding the Business Environment $(n=243)$} \\
\hline Major & Management & Marketing & Accounting & Finance & IS \\
\hline Mean & $98.02 * * *$ & $93.38 * * *$ & $92.64^{* * *}$ & $91.11^{* * *}$ & 81.91 \\
\hline \multicolumn{6}{|c|}{ Understanding the Competitive Environment $(n=243)$} \\
\hline Major & Marketing & Management & Finance & Accounting & IS \\
\hline Mean & $97.57 * * *$ & $96.01 * * *$ & $83.10^{* * *}$ & $76.04^{* * *}$ & 69.80 \\
\hline \multicolumn{6}{|c|}{ Understanding Financial Statements $(n=242)$} \\
\hline Major & Accounting & Finance & Management & Marketing & IS \\
\hline Mean & $98.85 * * *$ & $96.39 * * *$ & $86.37 * * *$ & $66.13^{* * *}$ & 59.87 \\
\hline \multicolumn{6}{|c|}{ Interpersonal Skills $(n=243)$} \\
\hline Major & Management & Marketing & Finance & Accounting & IS \\
\hline Mean & $97.13^{* * *}$ & $93.07 * * *$ & $78.18^{* * *}$ & $75.52^{* * *}$ & 68.92 \\
\hline \multicolumn{6}{|c|}{ Leadership Skills $(n=235)$} \\
\hline Major & Management & Marketing & Finance & Accounting & IS \\
\hline Mean & $97.48^{* * *}$ & $81.75^{* * *}$ & $71.49 * * *$ & $71.32^{* * *}$ & 60.79 \\
\hline \multicolumn{6}{|c|}{ Negotiation Skills $(n=240)$} \\
\hline Major & Management & Marketing & Finance & Accounting & IS \\
\hline Mean & $95.67 * * *$ & $79.00 * * *$ & $70.91^{* * *}$ & $60.87 * * *$ & 49.38 \\
\hline \multicolumn{6}{|c|}{ Speaking/Presentation Skills $(n=245)$} \\
\hline Major & Marketing & Management & Finance & Accounting & IS \\
\hline Mean & $97.18 * * *$ & $96.76 * * *$ & $74.85 * * *$ & $71.07 * * *$ & 61.07 \\
\hline
\end{tabular}




\begin{tabular}{|l|l|l|l|l|l|}
\hline \multicolumn{7}{|c|}{ Ability to Work in a Team (n=245) } \\
\hline Major & Management & Marketing & Finance & Accounting & IS \\
\hline Mean & $96.47^{* * *}$ & $94.54 * * *$ & $81.40^{* * *}$ & $81.07 * * *$ & 73.6 \\
\hline \multicolumn{7}{|c|}{ Writing Skills (n=241) } \\
\hline Major & Marketing & Management & Finance & Accounting & IS \\
\hline Mean & $91.41^{* * *}$ & $89.37 * * *$ & $74.87 * * *$ & $74.19 * * *$ & 70.18 \\
\hline$*$ p-value $<.05 ; * *$ p-value $<.01 ; * * *$ p-value $<.001$ & \\
\hline
\end{tabular}

On understanding the business environment, information systems scored almost 10 points lower than finance, the next highest field. In understanding the competitive environment, IS was last again, 6.24 points below accounting and 27.77 points below marketing. IS was perceived to require the lowest level of understanding of financial statements, almost 39 points behind accounting and slightly over 6 points behind marketing.

Interpersonal skills were considered the least necessary for IS, with IS rated 6.6 points below accounting, the next highest, and 28 points below management. Leadership skills were perceived to be less important for IS majors, with a difference of over 10 points between IS and accounting, the next lowest in rank. Management received the highest rating in leadership and was 37 points above IS. On negotiation skills, IS lagged 11 points behind accounting and a full 46 points behind management. Again, IS was last for speaking/presentation skills, 10 points behind accounting and about 36 points behind management and marketing. The ability to work on a team was perceived to be more important for the other four majors than for IS, and finally, writing skills were perceived to be the lowest for IS, slightly higher for finance and accounting majors, and the highest for marketing and management majors.

\section{Discussion and Conclusion}

This study reports the perceptions of secondary school business teachers on the business and communication skills required to succeed in specific business majors. The results suggest that secondary school business teachers have the same negative perception towards the IS field as secondary school students. The implication is that they would be more likely to point students with good communication and business skills away from a career in IS and to another business discipline. This highlights a significant barrier to the IS profession's effort to attract highly talented students into the field. If secondary school business teachers have an inaccurate picture of what it takes to succeed in IS, many students who might otherwise have chosen an IS major may be steered elsewhere. Alternatively, many students who lack the requisite KSAs to succeed in the IS profession may be attracted to it because of the inaccurate perceptions of IS conveyed to them by their secondary school business teachers. Either situation is detrimental to the IS profession.

One of the fundamental causes is likely due to the fact that a very important group of role models to whom students look for career advice (i.e., secondary school teachers in general and business teachers in particular) have an inaccurate and negative view of the information systems or information technology profession. Educational efforts to change perceptions might be more effective and efficient if initially directed at this important group of role models.

Focusing on teachers is more efficient because for every teacher educated and convinced about the merits of the profession, they will in turn share this with numerous students thereby leveraging the profession's efforts. Focusing on teachers is also potentially more effective than directing the educational efforts solely at students. The profession can share information with students, but 
Berry, O'Bryan, \& Cummings

convincing them will be much more difficult if students get conflicting advice from their secondary school teachers. At best, this sends a mixed signal and dilutes the effectiveness of our message.

This study is subject to the following limitations. First, survey research is inherently susceptible to non-response bias. A comparison of early and late responders revealed no significant differences, but non-response bias could still exist. Second, respondents to this survey were all from the state of Illinois and may not be generalizable to other states, regions, or countries. Third, this survey focused on a limited number of KSAs needed by business professionals. Secondary school business teachers' perceptions of information systems on other attributes (e.g., income potential) may be more encouraging. Fourth, this survey was administered prior to the collapse of the dot com bubble. The extent to which secondary school educators' perceptions have changed due to this collapse is an empirical question. However, it is doubtful that the dot com collapse would have caused their perceptions to improve relative to the results reported in this study. Lastly, a maintained premise of this study was that secondary school business teachers would be more knowledgeable about business majors in general, and information systems in particular, than their non-business teacher colleagues. If true, non-business secondary school teachers could be even more inaccurate in their perceptions of the KSAs needed to succeed in the information systems profession. However, this remains an empirical question that could be addressed by future research.

\section{References}

Abtan, P. (1993, March 1). The gender gap. Computing Canada, p. 9.

Brown, D. (2003). It won't always be easy finding IT workers. Canadian HR Reporter, 16 (11), June 2, p. 2.

Chabrow, E. (2003, October 20). Jobless recovery. InformationWeek, p. 19.

Dodson, N. J. \& Price, J. C. (1991, September-October). Who is tomorrow's CPA? The Ohio CPA Journal, pp. 9-14.

Graves, O. F., Nelson, I. T. \& Deines, D. (1993). Accounting student characteristics: Results of the 1992 federation of schools of accountancy (FSA) survey. Journal of Accounting Education, 11, 211-225.

Information Technology Association of America (ITAA). (1998, January) Changing the image of information technology professions. Alexandria, Virginia.

Information Technology Association of America (ITAA). (2002, May). Bouncing back: Jobs, skills and the continuing demand for IT workers. Alexandria, Virginia.

Institute of Management Accountants (IMA). (1996). The practice analysis of management accounting. Montvale, NJ.

McGee, M. K. (2001, January 8). Outlook for 2001. InformationWeek, pp. 43-52.

McGee, M. K., Chabrow, E., \& Hayes, M. (2003, April 28). Sliver of the pie. InformationWeek, 937, pp. 36-46.

Medlin, B. D., Dave, D. S. \& Vannoy, S. A. (2001). Students' view of the importance of technical and nontechnical skills for successful IT professionals. Journal of Computer Information Systems, Fall, 65-69.

Nelson, I. T. \& Deines, D. S. (1995). Accounting student characteristics: Results of the 1993 and 1994 federation of schools of accountancy (FSA) surveys. Journal of Accounting Education, 13 (4), 393-411.

Paolillo, J. G. P. \& Estes, R. W. (1982). An empirical analysis of career choice factors among accountants, attorneys, engineers, and physicians. The Accounting Review, October, 785-793.

Siegel, G., \& Sorensen, J. E. (1999). Counting more, counting less: Transformations in the management accounting profession. Institute of Management Accountants. Montvale, N.J. 
Weber, J. E., McIntyre, V. J. \& Schmidt, M. (2001). Explaining IS student and IS industry differences in perceptions of skill importance. Journal of Computer Information Systems, Summer, 79-83.

Young, D. (1996). The relative importance of technical and interpersonal skills for new information systems personnel, Journal of Computer Information Systems, Summer, 66-71.

\section{Appendix}

\section{Survey of Educators' Opinions toward Business Majors}

The following is a reproduction of the research instrument with the mean responses reported in each cell.

Listed in the left column of the table below are knowledge, skills or abilities that a potential business major may possess. On a scale of 0 (lowest level of ranking) to 100 (highest level), please rate the five business majors listed according to your personal opinion as to the knowledge, skills, and abilities required to succeed in that major. For example, a business major that you feel requires a high level of artistic skill might receive a score of 100; a business major which you feel requires a low level of artistic skill might receive a score of 0 .

\begin{tabular}{|l|r|r|c|r|r|}
\hline Knowledge, skills, and abilities & Accounting & Finance & IS & Management & Marketing \\
\hline Ability to work on a team & 81.07 & 81.40 & 73.60 & 96.47 & 94.54 \\
\hline $\begin{array}{l}\text { Analytical/problem-solving } \\
\text { skills }\end{array}$ & 92.86 & 90.28 & 90.23 & 91.84 & 82.46 \\
\hline Interpersonal skills & 75.52 & 78.18 & 68.92 & 97.13 & 93.08 \\
\hline Leadership skills & 71.32 & 71.49 & 60.79 & 97.48 & 81.95 \\
\hline Listening skills & 84.96 & 85.05 & 83.09 & 98.23 & 95.91 \\
\hline Mathematical skills & 96.55 & 97.85 & 78.93 & 80.56 & 76.42 \\
\hline Negotiation skills & 60.87 & 70.91 & 49.38 & 95.67 & 79.00 \\
\hline Speaking/presentation skills & 71.09 & 74.85 & 61.07 & 96.76 & 97.18 \\
\hline $\begin{array}{l}\text { Understanding the information } \\
\text { needs of internal customers }\end{array}$ & 75.32 & 73.42 & 80.14 & 92.28 & 82.27 \\
\hline $\begin{array}{l}\text { Understanding/preparing } \\
\text { financial statements }\end{array}$ & 98.85 & 96.39 & 59.87 & 86.37 & 66.13 \\
\hline $\begin{array}{l}\text { Understanding the business } \\
\text { environment }\end{array}$ & 92.64 & 91.11 & 81.91 & 98.02 & 93.38 \\
\hline $\begin{array}{l}\text { Understanding the competitive } \\
\text { environment }\end{array}$ & 76.04 & 83.10 & 69.80 & 96.16 & 97.57 \\
\hline Work ethic & 97.74 & 97.17 & 96.77 & 98.37 & 97.19 \\
\hline Writing skills & 74.19 & 74.87 & 70.18 & 89.37 & 91.41 \\
\hline
\end{tabular}




\section{Demographic Data}

\section{Highest educational level}

- Bachelor's $34.3 \%$

- Master's $\quad 63.6 \%$

- Specialist's $\mathbf{1 . 7 \%}$

- Doctorate $\mathbf{0 . 4 \%}$

\section{Years as secondary school teacher}

- $\quad$ Mean $=18.77$ years

\section{Gender}

- Male 30.0\%

- Female $70.0 \%$

\section{Age}

- Mean $=45.43$ years

\section{Biographies}

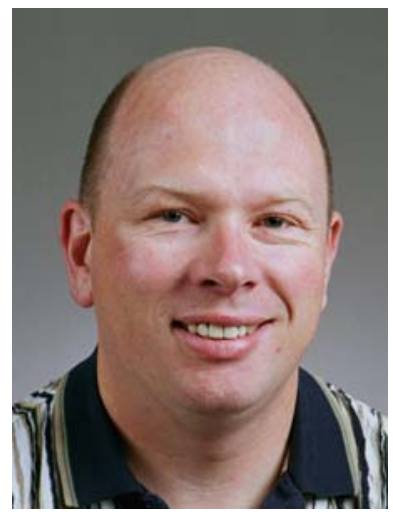

Kevin T. Berry is an Assistant Professor of Accounting at Bradley University. He has published in numerous journals including Journal of Business Finance \& Accounting, Journal of Accounting Education, Journal of Accounting Case Research, Journal of Energy Finance \& Development, Petroleum Accounting and Financial Management Journal, and The Mid-Atlantic Journal of Business.

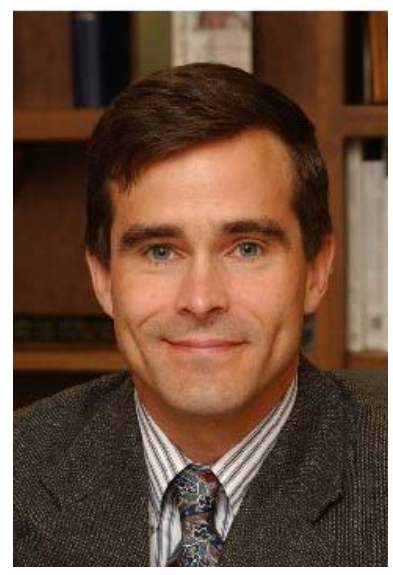

David O'Bryan, Ph.D., CPA, CMA, CFM, CFE, is an Associate Professor and Chairperson of the Department of Accounting at Pittsburg State University. He has published in numerous journals including Behavioral Research in Accounting, Advances in Accounting, Journal of Energy Finance \& Development, Journal of Forensic Accounting, Advances in Accounting Behavioral Research, Advances in Management Accounting, Journal of Business Finance \& Accounting, Journal of Accounting Education, and Journal of Accounting Case Research. The Kansas Society of CPAs has recognized him as the 2002 Kansas Accounting Educator of the Year. His current research interests include dysfunctional audit behaviors, budgeting and performance evaluation processes, forensic accounting, and accounting pedagogy. 


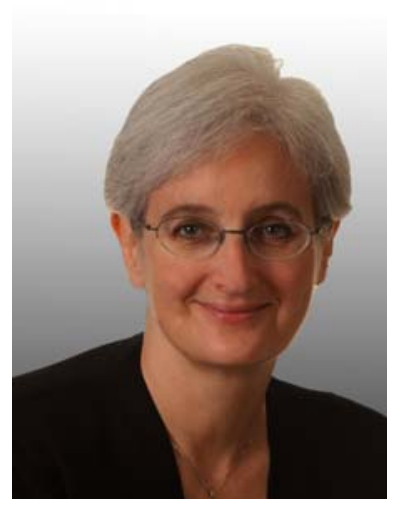

Maeve Cummings is a professor Information Systems at Pittsburg State University. She holds a B.S. in Mathematics and Computer Science; an M.S. in Mathematics; and an M.B.A. from Pittsburg State University; and a Ph.D. in Information Systems from the University of Texas at Arlington. She has published in various journals, and is also on numerous editorial boards. She has co-authored several textbooks, including Management Information Systems for the Information Age, now in its fourth edition, and I-Series: Computing Concepts, now in its second edition. 